\title{
Analysis of Chromosomal Abnormalities at Anaphase-Telophase Induced by Sodium Fluoride In Vitro
}

\author{
S. S. Bale \\ Professor, Department of Natural Science and Mathematics, Saint Paul's \\ College, 406 Windsor Avenue, Lawrenceville, Virginia, U.S.A. \\ and \\ M. T. Mathew \\ Chairman, Department of Biology, Virginia Union University, \\ Richmond, Virginia, U.S.A.
}

Accepted March 4, 1987

In recent years, discharge of industrial wastes and the application of chemicals to the natural environment have caused air, water, and soil pollution. The contamination with these chemicals has created potential hazards as mutagens, teratogens, and/or carcinogens to both plants and animals life, including humans.

Fluorocompounds are potential air pollutants in both rural and urban areas. Earlier studies on the cytogenetic effects of fluoride have been conducted primarily in plants. Sodium fluoride in concentration of $1 \times 10^{-8} \mathrm{M}$ or higher was shown to induce chromosomal abnormalities in onion (Mohamed et al. 1966a), tomato plants (Mohamed et al. 1966b), maize (Mohamed 1970), and barley (Bale and Hart 1973a, b). Jachimczak and Skotarczak (1978) showed that fluoride causes chromosomal abnormalities in cultured leucocytes. In vitro treatment of oocytes from mice, ewes, and cows with sodium fluoride induced chromosomal abnormalities (Jagiello and Lin 1974). On the other hand some investigators have pointed out that fluoride at low concentration failed to produce chromosomal anomalies (Kram et al. 1978, Leonard et al. 1977, Obe and Slacik-Erben 1973).

Sodium fluoride has been reported to induce morphological and neoplastic transformation, chromosomal abnormalities, sister chromatid exchanges, and unscheduled DNA synthesis (Tsutsui et al. 1984a, b, c).

The primary objective of this study was to attempt to observe any effects of fluoride on Don Chinese hamster cells. This objective was approached by analyzing different types of chromosomal abnormalities encountered after treatment of cells with various concentrations of fluoride.

\section{Materials and methods}

\section{Chemicals}

Technical grade sodium fluoride was purchased from Fisher Scientific Company. Alpha minimum essential medium (Alpha MEM), fetal bovine serum, and trypsin EDTA were purchased from K. C. Biological Company. Gentamycin was purchased from Schreing Corporation.

\section{Anaphase-Telophase Test}

Don Chinese hamster cells were obtained from the American Type Culture Collection. The cells were grown in $25 \mathrm{~cm}^{2}$ disposable plastic flasks in a carbon dioxide incubator at $37^{\circ} \mathrm{C}$. 
Alpha MEM supplemented with $10 \%$ fetal bovine serum and $50 \mu \mathrm{g} / \mathrm{ml}$ gentamycin was used for experimental cultures.
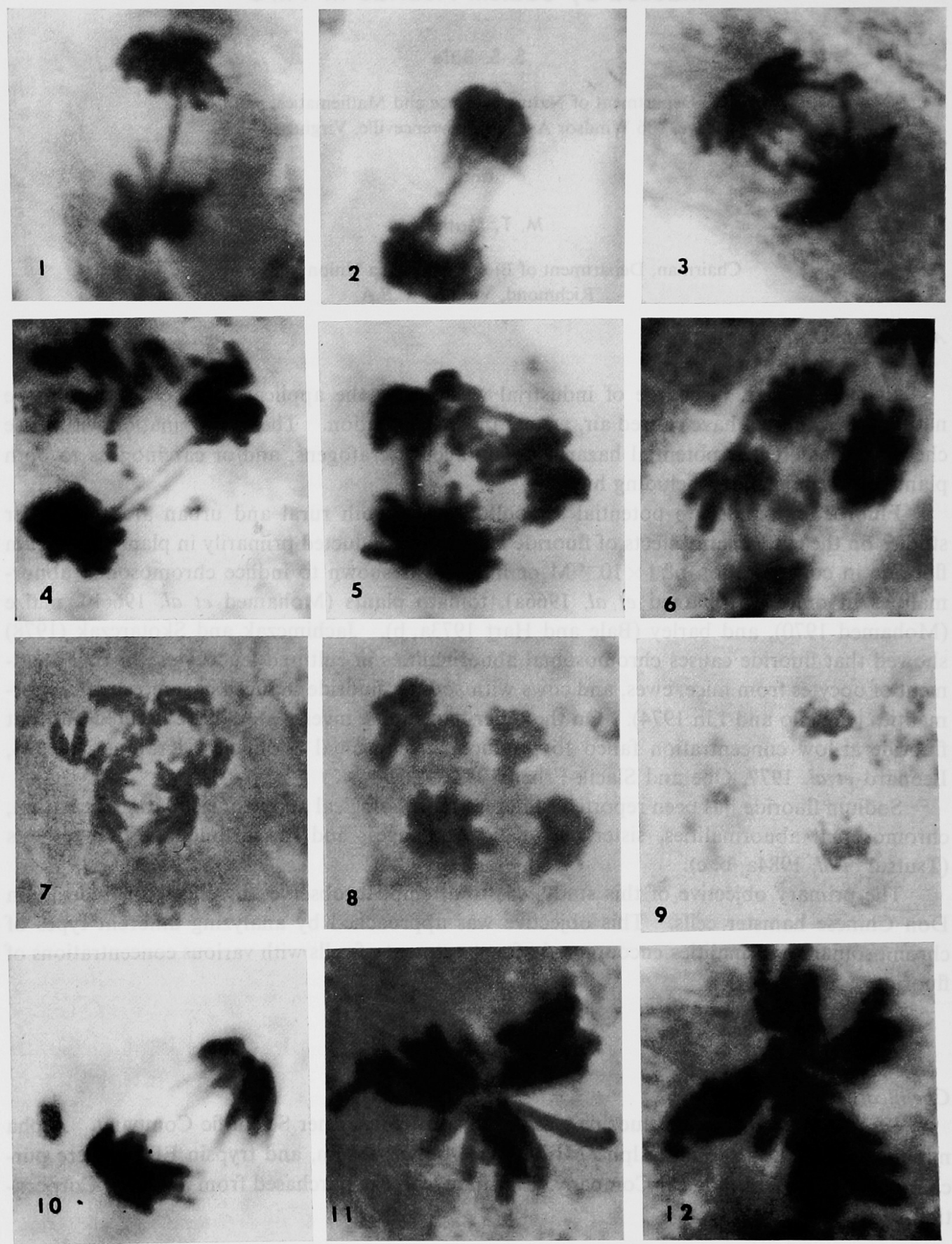

Figs. 1-12. Types of chromosomal abnormalities induced by sodium fluoride in Don Chinese hamster cells. 1 , bridge. 2 , double bridge. 3 , sidearm bridge. 4 , bridge with fragments. 5 , tripolar anaphase with bridge. 6 , multipolar anaphase with bridge. 7 , tripolar anaphase. 8 , multipolar anaphase. 9, fragments. 10 , laggard. 11 , ' $Y$ ' metaphase. 12, ' $X$ ' metaphase. 
For Anaphase-Telophase tests, approximately $1 \times 10^{5}$ cells were seeded in Tissue-tek flaskettes and allowed to grow for 12 hours. The flaskettes were replaced with fresh medium containing $0 \mu \mathrm{g}, 25 \mu \mathrm{g}, 50 \mu \mathrm{g}$, and $75 \mu \mathrm{g} / \mathrm{ml}$ of sodium fluoride (NaF). At the end of each treatment period, the cells were washed with phosphate buffered saline and fixed with Carnoy's solution ( 1 part glacial acetic acid and 3 parts of methanol). The slides were separated from the flaskettes and the cells were flame fixed. They were stained with acetocarmine or aceto-

Table 1. Types and frequencies of chromosomal abnormalities observed in Don Chinese hamster cells after treatment with sodium fluoride

\begin{tabular}{|c|c|c|c|c|c|c|c|c|c|c|}
\hline \multicolumn{2}{|c|}{$\begin{array}{c}\text { Concentration } \\
\text { and treatment } \\
\text { period }\end{array}$} & $\begin{array}{l}\text { Num- } \\
\text { bers of } \\
\text { cells } \\
\text { scored }\end{array}$ & $\begin{array}{l}\text { Frag- } \\
\text { ments }\end{array}$ & Bridges & $\begin{array}{c}\text { Bridges } \\
+ \\
\text { frag- } \\
\text { ment }\end{array}$ & $\begin{array}{l}\text { Sidearm } \\
\text { bridge }\end{array}$ & $\begin{array}{l}\text { Tripolar* } \\
\text { anaphase }\end{array}$ & $\begin{array}{l}\text { Multi- } \\
\text { polar* } \\
\text { anaphase }\end{array}$ & Laggard & $\begin{array}{c}\text { Total } \\
\%\end{array}$ \\
\hline $0 \mu \mathrm{g} / \mathrm{ml}$ & \multirow{4}{*}{$12 \mathrm{hrs}$} & 200 & 5 & 10 & 0 & 1 & 2 & 0 & 3 & 10.5 \\
\hline $25 \mu \mathrm{g} / \mathrm{ml}$ & & 200 & 12 & 22 & 1 & 6 & 2 & 0 & 1 & 22.0 \\
\hline $50 \mu \mathrm{g} / \mathrm{ml}$ & & 200 & 10 & 26 & 2 & 2 & 4 & 1 & 3 & 24.0 \\
\hline $75 \mu \mathrm{g} / \mathrm{ml}$ & & 200 & 11 & 16 & 2 & 6 & 2 & 1 & 2 & 20.0 \\
\hline $0 \mu \mathrm{g} / \mathrm{ml}$ & \multirow{4}{*}{$24 \mathrm{hrs}$} & 200 & 6 & 9 & 1 & 2 & 1 & 0 & 0 & 9.5 \\
\hline $25 \mu \mathrm{g} / \mathrm{ml}$ & & 200 & 16 & 30 & 6 & 2 & 1 & 2 & 3 & 30.6 \\
\hline $50 \mu \mathrm{g} / \mathrm{ml}$ & & 200 & 12 & 34 & 0 & 0 & 4 & 1 & 3 & 27.0 \\
\hline $75 \mu \mathrm{g} / \mathrm{ml}$ & & 200 & 18 & 38 & 8 & 0 & 5 & 0 & 1 & 35.0 \\
\hline $0 \mu \mathrm{g} / \mathrm{ml}$ & \multirow{4}{*}{$36 \mathrm{hrs}$} & 200 & 5 & 11 & 1 & 2 & 1 & 0 & 0 & 15.0 \\
\hline $25 \mu \mathrm{g} / \mathrm{ml}$ & & 200 & 6 & 29 & 5 & 0 & 4 & 0 & 4 & 24.0 \\
\hline $50 \mu \mathrm{g} / \mathrm{ml}$ & & 200 & 7 & 39 & 2 & 0 & 0 & 2 & 3 & 26.0 \\
\hline $75 \mu \mathrm{g} / \mathrm{ml}$ & & 200 & 7 & 35 & 4 & 3 & 3 & 1 & 1 & 27.0 \\
\hline
\end{tabular}

* With or without bridge.

Table 2. Analysis of variance for the total chromosomal aberrations induced by sodium fluoride in Don Chinese hamster cells

\begin{tabular}{lcccc}
\hline \hline Source of variation & Degrees of freedom & Sum square & Mean square & F \\
\hline Total & 11 & 649.23 & & \\
Treatments & 3 & 479.56 & 159.85 & $8.52^{*}$ \\
Periods & 2 & 57.11 & 28.53 & 1.52 \\
Error & 6 & 112.56 & 18.76 & \\
\hline
\end{tabular}

* Significant at 1 and $5 \%$ probability level.

Table 3. Duncan Multiple Range Test for the total chromosomal abnormalities induced by sodium fluoride in Don Chinese hamster cells

\begin{tabular}{lccll}
\hline Concentration & $0 \mu \mathrm{g} / \mathrm{ml}$ & $25 \mu \mathrm{g} / \mathrm{ml}$ & $50 \mu \mathrm{g} / \mathrm{ml}$ & $75 \mu \mathrm{g} / \mathrm{ml}$ \\
Mean* & 11.66 & 25.33 & 25.83 & 27.33 \\
\hline
\end{tabular}

* Values connected by the same line do not differ significantly at the $5 \%$ probability level.

orcein and made permanent. Chromosomal abnormalities were scored using late anaphase and early telophase stages.

Results

Chromosomal abnormalities induced by $\mathrm{NaF}$ in Don Chinese hamster cells are presented in Table 1. NaF induced chromosomal aberrations in all the concentrations used. A 24 hour 
period of treatment in all concentrations of fluoride produced maximum effect. Cytological observations made at anaphase and telophase stages revealed several kinds of abnormalities. The chief abnormalities observed were bridges, double bridges, sidearm bridges, bridges with fragments, tripolar and multipolar anaphases with or without bridges, fragments, and laggards (Figs. 1-10). In addition to these abnormalities ' $Y$ ' and ' $X$ ' configurations were also observed at metaphase (Figs. 11, 12). Bridges and fragments were common in most of the treatments.

A statistical analysis of the total chromosomal abnormalities observed following $\mathrm{NaF}$ treatment for varying periods showed that the mean square for the treatments was statistically significant. However, mean square for the periods was not significant (Table 2).

A Duncan's multiple range test was employed to compare the treatment means. The effect of fluoride at all levels used was found to be non-significant. However, the effects of $25 \mu \mathrm{g}, 50 \mu \mathrm{g}$, and $75 \mu \mathrm{g} / \mathrm{ml}$ of NaF were significant at the $5 \%$ probability level as compared to control (Table 3).

\section{Discussion}

It is clear that each of the concentrations of $\mathrm{NaF}$ is capable of inducing chromosomal abnormalities. It appears that a 24 hour period for all the levels of fluoride produced the maximum effect. The statistical analysis for chromosomal abnormalities revealed the results to highly significant.

Bridges scored in anaphase-telophase may be due to stickiness of chromosomes or due to exchange between chromosomes or chromatids (Davidson 1957). However, it is not clearly established whether naturally occurring and fluoride induced bridges are of the same type. Lagging chromosomes or fragments observed can originate from alterations of the mitotic spindle, or of the centromere, or from chromosome or chromatid breaks (Dulot and Olivero 1984). The fragments and laggards appeared as micronuclei at a later stage.

It has been shown that $\mathrm{NaF}$ affects the rate of protein synthesis (Chang 1970, Vesco and Colombo 1970). Since the mitotic spindle fibers are composed of proteins, it is apparent that fluoride could be responsible for the disruption of microtubules, causing ' $Y$ ' and ' $X$ ' type of configurations in metaphase. Such disorientation may produce tripolar and multipolar anaphases.

Although some investigators (Kram et al. 1978, Leonard et al. 1977, Obe and SlacikErben 1973) have indicated that fluoride is unable to produce chromosome abnormalities, the present study indicates that $\mathrm{NaF}$ can induce chromosomal changes in Don Chinese hamster cells. Similar observations were made in other mammalian cells by other investigators (Jachimaczak and Skotarczak 1978, Mohamed and Chandler 1982, Tsutsui et al. 1984a, b).

The foregoing observations have shown that exposure of Don cells to NaF induced a variety of chromosomal abnormalities and thus fluoride may be considered to be clastogenic.

\section{Summary}

The effect of treatment of cultured Don Chinese hamster cells with sodium fluoride has been investigated with respect to induction of chromosomal abnormalities. Exposure of Don Chinese hamster cells to sodium fluoride $(25 \mu \mathrm{g} / \mathrm{ml}, 50 \mu \mathrm{g} / \mathrm{ml}$, and $75 \mu \mathrm{g} / \mathrm{ml})$ induced a higher frequency of chromosomal abnormalities as compared to control. The observed abnormalities included were bridges, bridges with fragments, sidearm bridges and tripolar and multipolar anaphases. Bridges and fragments were the most common type of abnormalities observed in all treatments. 


\section{References}

Bale, S. S. and Hart, G. E. 1973a. Studies on the cytogenetic and genetic effects of fluordie on barley I. A comparative study of the effects of sodium fluoride and hydrofluoric acid on seedling root tips. Can. J. Genet. Cytol. 15 : 695-702.

- and - 1973b. Studies on the cytogenetic and genetic effects of fluoride on barley II. The effects of treatments of seedling coleoptiles with sodium fluoride. Can J. Genet. Cytol. 15: 703-712.

Chang, C. W. 1970. Effect of fuoride on ribosomes from corn roots. Changes with growth retardation. Phys. Plant. 23: 536-543.

Davidson, D. 1957. The irradiation of dividing cells I. The effect of X-rays on prophase chromosomes. Chromosoma 9: 39-60.

Dulot, F. N. and Olivero, O. A. 1984, Anaphase-Teleophase analysis of chromosomal damage induced by chemicals. Environ. Mutagen. 6: 299-310.

Jachimaczak, and Skotarczak, B. 1978. The effect of fluoride ions on the chromosomes of human leucocytes in vitro. Genet. Pol. 19: 353-357.

Jagiello, G. and Lin, J. 1974. Sodium fluoride as potential mutagen in mammalian eggs. Arch. Environ. Health $29: 230-235$.

Kram, D., Schneider, E. L., Singer, L. and Martin, G. R. 1978. The effects of high and low fluoride diets on the frequencies of sister chromatid exchanges. Mutation Res. 57: 51-55.

Leonard, A., Dekundt, G. H., Decat, G. and Leonard, E. D. 1977. Cytogentic investigations on leucocytes of cattle intoxicated with fluoride. Toxicology $7: 239-242$.

Mohamed. A. H. 1970. Chromosomal changes in maize induced by hydrogen fluoride gas. Can. J. Genet. Cytol. 12: 614-620.

— and Chandler, M. E. 1982. Cytological effects of fluoride in mice. Fluoride 15: 110-118.

-, Applegate, H. G. and Smith, J. D. 1966a. Cytological reactions induced by sodium fluoride in Allium cepa root tip chromosomes. Can. J. Genet. Cytol. 8: 241-244.

-, Smith, J. D. and Applegate, H. G. 1966b. Cytological effects of hydrogen fluoride on tomato chromosomes. Can. J. Genet. Cytol. 8: 575-583.

Obe, G. and Slacik-Erben, R. 1973. Suppressive activity by fluoride on the induction of chromosome aberrations in human cells with alkylating agents in vitro. Mutation Res. 19: 369-371.

Tsutsui, T., Suzuki, N. and Ohmori, M. 1984a. Sodium fluoride induced morphological and neoplastic transformation, chromosomal aberrations, sister chromatid exchanges, and unscheduled DNA synthesis in cultured Syrian hamster embryo cells. Cancer Res. 44: 938-941.

-, -, - and Maizumi, H. 1984b. Cytotoxicity, chromosome aberrations, and unscheduled DNA synthesis in cultured human diploid fibroblasts induced by sodium fluoride. Mutation Res. 139: 193-198.

-, Ide, K. and Maizumi, H. 1984c. Induction of unscheduled DNA synthesis in cultured human keratinocytes by sodium fluoride. Mutation Res. 140: 43-48.

Vesco, C. and Colombo, B. 1970. Effect of sodium fluoride on protein synthesis in HeLa cells: Inhibition of ribosome dissociation. J. Mol. Biol. 47: 335-352. 